\title{
Cattle Selection for Aspen and Meadow Vegetation: Implications for Restoration
}

\author{
Bobette E. Jones, ${ }^{1}$ David F. Lile, ${ }^{2}$ and Kenneth W. Tate ${ }^{3}$
}

Authors are ${ }^{1}$ District Ecologist, United States Forest Service, Eagle Lake Ranger District, Lassen National Forest, Susanville, CA 96130, USA; ${ }^{2}$ Livestock and Natural Resources Advisor, University of California Cooperative Extension, Lassen County, Susanville, CA 96130, USA; and ${ }^{3}$ Rangeland Watershed Specialist, Department of Plant Sciences, University of California, Davis, CA 95616, USA.

\begin{abstract}
There is concern over the decline of aspen and the lack of successful regeneration due to excessive browsing of aspen suckers by cattle and other wild and domestic ungulates. We conducted a 2-yr study on Lassen National Forest, California, to aid development of cattle grazing strategies to enhance aspen regeneration. We evaluated seasonal biomass, nutritional quality, and utilization by cattle of aspen suckers, aspen herbaceous understory vegetation, and meadow herbaceous vegetation within six aspen-meadow complexes. Aspen suckers had greater nutritional quality compared to aspen understory and meadow vegetation regardless of season or year. Nutritional quality declined with season in all three vegetation types. Early-growing season foraging by cattle focused on meadow and aspen understory vegetation. Mid-growing season decreases in meadow and aspen understory nutritional quality coincided with a marked increase in utilization of aspen suckers. By late-growing season, utilization on aspen suckers was significantly greater than aspen understory or meadow vegetation. Managers can use earlygrowing season grazing to reduce aspen consumption by cattle, set stocking rates so that adequate herbaceous vegetation is available throughout the growing season, provide nutritional supplements to reduce demand for nutritious aspen suckers, construct protective fencing, and implement grazing systems that insure years with mid- and late-growing season rest from heavy browsing.
\end{abstract}

\section{Resumen}

Existe la preocupación por la disminucion del alamo y la falta de resultados en la regeneracion debido al excesivo ramoneo de las yemas de los alamos por el ganado y otro ungulados silvestres y domesticos. Realizamos un estudio de dos años en el Bosque Nacional Lassen en California en EUA para ayudar a desarrollar estrategias de pastoreo del ganado que estimulen la regeneracion del alamo. Evaluamos la biomasa estacional, calidad nutricional y utilización por el ganado de las yemas del aspen, la vegetación herbacea debajo del alamo y la vegetación herbacea de pradera dentro de seis complejos de alamo-pradera. Las yemas del alamo tuvieron la mas alta calidad nutricional comparada con la vegetación debajo del alamo y la vegetación de pradera independientemente, de la temporada del año. La calidad nutricional disminuyo con la temporada en los tres tipos de vegetación. Al inicio de la temporada de crecimiento el ganado se inclino por la vegetacion debajo del alamo. A mitad de la temporada de crecimiento disminuyo la calidad nutricional de la pradera y la vegetacion de abajo del alamo coincidiendo, con un marcado incremento en la utilizacion de las yemas de alamo. Al final de la temporada de crecimiento la utilizacion de las yemas de alamo fue significativamente mayor que la de la pradera y de abajo del alamo. Los administradores pueden implementar pastoreo al inicio de la temporada de crecimiento para reducir el consumo de alamo por el ganado, establecer la carga animal previendo la disponibilidad adeucada de vegetacion herbacea a través de la temporada de crecimiento, usar suplemento nutricional para reducir la demanda de la nutritiva yema de alamo, construir cercos de proteccion e implementar sistemas de pastoreo que aseguren años con descansos de ramoneo intenso a mediados y finales de la temporada de crecimiento.

Key Words: browsing, forage quality, grazing, nutritional quality, Populus tremuloides, ungulates

\section{INTRODUCTION}

Decline of aspen (Populus tremuloides Mich.) health and extent has been reported throughout western North America (Bartos and Campbell 1998; White et al. 1998; Rogers 2002; Frey et al. 2004; Di'Orio et al. 2005; Worrall et al. 2008). Aspen stand decline is spatially and temporally heterogeneous with some regions realizing aspen persistence (Kulakowski et al. 2004, 2006; Binkley 2008; Sankey 2008). There are also regions where aspen is used as a forage base and livestock grazing is used to manage aspen (Semiadi et al. 1995; McWilliam et al. 2005).

\footnotetext{
Correspondence: Kenneth W. Tate, Dept of Plant Sciences, University of California, Mail Stop One, One Shields Ave, Davis, CA 95616, USA. Email: kwtate@ucdavis.edu

Manuscript received 1 June 2010; manuscript accepted 6 July 2011.
}

In regions with aspen decline, stand restoration depends on successful vegetative regeneration by suckering between episodic seeding events (Eriksson 1993; Romme et al. 1997). Altered disturbance regimes due to fire suppression and heavy wild and domestic ungulate browse suppress aspen regeneration (DeByle 1985; Mueggler 1985; Chong et al. 2001; Frey et al. 2004; Kouki et al. 2004; Kaye et al. 2005; Kashian et al. 2007; Worrall et al. 2008). Lengthened fire return intervals allow conifers to establish in seral aspen stands, which creates an environment that hinders aspen regeneration (Schier 1976; Bartos 2001; Kaye et al. 2005). Aspen may fail to regenerate if suckers are browsed excessively by livestock or wildlife (Kay 1993; Baker et al. 1997; Kaye et al. 2005).

Aspen restoration in grazed landscapes is a priority for many resource managers (Jones et al. 2005; Shepperd et al. 2006; Bartos 2007). Stand protection practices such as exclusionary fencing are 
often recommended where browsing is suppressing aspen regeneration (Bartos and Campbell 1998; Kay 2001; Rolf 2001). However, wide-spread exclusionary fencing of stands may not be ecologically or economically practical (Rolf 2001). For example, on Eagle Lake Ranger District (ELRD) Lassen National Forest (LNF), over 250 aspen stands need protection from excessive cattle browse (ELRD, LNF database). Management of season, intensity, and frequency of browse is an alternative to exclusionary fencing, and we have found that these factors determine aspen sucker growth response to defoliation (Jones et al. 2009). Grazing management strategies to restore aspen must be designed to account for seasonal biomass and nutritional quality differentials between aspen suckers and other available vegetation types (i.e., meadow and aspen understory herbaceous vegetation).

Cattle preferentially consume certain plant species and parts within and among plant communities (Arnold and Dudzinski 1978). Structural or compositional modification of woody plants has been observed in many studies especially with late season grazing (Roath and Krueger 1982; Kauffman et al. 1983; Green and Kauffman 1995). Cattle foraging preferences may target certain plant species and communities, and result in species and community decline (Pinchak et al. 1991). Growth rates for browsing-prone trees generally decline with increasing browsing levels, with complete regeneration failure at high browse pressure (Peterken and Tubbs 1965; Miller and Cummins 1982; Tilghman 1989; Zakrisson et al. 2007; Jones et al. 2009). Excessive browsing suppresses establishment of new aspen tree cohorts by maintaining suckers in a hedged form below the herbivore browse line, or by total elimination of suckers (Bartos et al. 1994; White et al. 1998; Kay and Bartos 2000; Kay 2001; Turner et al. 2003; Dockrill et al. 2004).

Diet selection by foraging cattle tends to favor maximal nutritional quality and adequate quantity (Belovsky 1984; Senft et al. 1987). Aspen tend to grow in patches, which presents a concentration of nutrients that may attract cattle. This exposes suckers to a great risk of browsing, particularly when aspen communities comprise a small percentage of the landscape and are adjacent to meadows, drinking water sources, or other cattle attractants. When aspen is growing in this context, incidental cattle browsing can impede aspen recruitment. Understanding seasonal dynamics of the biomass, nutritional quality and utilization of vegetation types found in aspen-meadow complexes may provide insight in understanding why cattle broaden their diet selection and start to browse aspen suckers. This information can be used to develop cattle grazing strategies to restore aspen stands that are in decline due to excessive livestock browsing. Our objectives were to quantify seasonal differences in: 1) nutritional quality among meadow herbaceous vegetation, aspen understory herbaceous vegetation, and aspen suckers; 2) biomass of meadow herbaceous vegetation and aspen understory herbaceous vegetation; and 3) utilization by cattle of meadow herbaceous vegetation, aspen understory herbaceous vegetation, and aspen suckers.

\section{METHODS}

\section{Study Area}

This study was conducted on ELRD, LNF, located in northeastern California in the southern Cascade Mountains (lat $40^{\circ} 23^{\prime} \mathrm{N}$, long $120^{\circ} 34^{\prime} \mathrm{W}$ ). The area has a Mediterranean climate with cool moist winters and dry warm summers.
Precipitation occurs as rain and snow from November to midMay with a distinct dry season from mid-May to October. Annual precipitation ranges from approximately $40 \mathrm{~cm}$ to $150 \mathrm{~cm}$ with mean monthly temperatures ranging from $4^{\circ} \mathrm{C}$ in January to $28^{\circ} \mathrm{C}$ in July.

The landscape consists of a mosaic of plant communities including riparian, meadow, sagebrush, aspen stands, and coniferous forest. At elevations less than $1800 \mathrm{~m}$, forests are dominated by eastside pine (mixture of Pinus ponderosa Laws. and Pinus jeffreyi Grev. \& Balf.), and at greater than $1800 \mathrm{~m}$ these forests transition to mixed conifer forests dominated by Abies concolor (Gordon \& Glend) Lindley, Pinus lambertiana Douglas, P. ponderosa, P. jeffreyi, and Calocedrus decurrens Torrey. Broad, open meadows separate conifer-covered buttes and are vegetated by grasses, shrubs, and forbs. The primary livestock forage found in the landscape is located in these open meadows and consists primarily of graminoid species (Achnatherum spp., Poa secunda J. Presl, Festuca idahoensis Elmer, Juncus balticus Willd., Carex nebraskensis Dewey, and Carex filifolia Nutt.) intermixed with native shrubs (Purshia tridentata [Pursh] DC.) and forbs (Trifolium longipeas Nutt., Lupinus argenteus Pursh). Aspen is a minor component in this landscape and covers approximately 1\% of the ELRD. Aspen stands are commonly associated with meadow edges, rocky outcrops, riparian areas, and areas with relatively high water tables. Aspen occur at 1500 to $2200 \mathrm{~m}$ in elevation, on $0-45 \%$ slopes across all aspects, and on mollisols, inceptisols, and alfisols.

Permitted grazing by cattle occurs annually on the ELRD from 1 June through 30 September. The ELRD is divided into grazing allotments ranging from 4050 ha to 12140 ha. Cattle numbers are based on meadow and upland forage quantity with herd size per allotment ranging from 150 to 800 animal units, typically cow-calf pairs. Livestock distribution practices include cross-fencing allotments into large pastures, herding, and location of water and mineral supplements. US Forest Service has established annual vegetation utilization standards for permitted grazing allotments. The annual utilization standard (limit) for aspen is a percentage of individual aspen suckers browsed, and the standard (limit) for meadow and aspen understory herbaceous vegetation utilization is a percentage of biomass consumed.

\section{Study Design and Site Selection}

This study was a cross-sectional, longitudinal survey of six study sites over two grazing/growing seasons from mid-May to October of 2006 and 2007. Each study site consisted of an aspen stand and an adjacent meadow. All study sites were located on season long continuous grazing allotments. The six study sites were selected along a grazing intensity gradient from light to heavy use of aspen suckers observed on the ELRD. Data from a previous aspen inventory on the ELRD (LNF database) were first used to identify a pool of potential aspen stands that met the following criteria: 1) adjacent to meadows, 2) on active cattle allotments, 3) annual deer browsing less than $5 \%$, and 4) less than $50 \%$ of stand overtopped by conifers. The stands that met these four criteria were then stratified into light $(<20 \%)$, moderate $(21 \%$ to $50 \%)$, and heavy ( $>50 \%)$ annual utilization of aspen suckers by cattle recorded during the ELRD 
Table 1. Dates of nutritional quality attribute, biomass, and utilization by cattle measurements taken during the summer growing seasons of 2006 and 2007. Percent of long-term average annual precipitation is reported (Annual P) for each year. Data were collected from six aspen-meadow complexes on the Eagle Lake Ranger District, Lassen National Forest, California.

\begin{tabular}{lcccc}
\hline & \multicolumn{3}{c}{ Period of annual grazing season } & Annual P (\%) \\
\cline { 2 - 4 } Year & Early & Mid & Late & 132 \\
\hline 2006 & 15 June-30 June & 25 July-5 August & 15 September-30 September & 49 \\
2007 & 25 May-15 June & 15 July-31 July & 1 September-15 September & 4 \\
\hline
\end{tabular}

aspen inventory. Two stands were then randomly selected from each utilization strata for inclusion in the study. The following aspen-meadow complexes were selected and are listed in order of increasing utilization of aspen suckers: Bogard Spring $(<20 \%$ use, aspen stand 16 ha, meadow 16 ha), Crowthers Hole $(<20 \%$ use, aspen stand 2 ha, meadow 40 ha), Little Antelope Valley $(21 \%$ to $50 \%$ use, aspen stand 1.2 ha, meadow 4 ha), Martin Creek ( $21 \%$ to $50 \%$ use, aspen stand 5 ha, meadow 80 ha), Shoestring Draw ( $>50 \%$ use, aspen stand 0.5 ha, meadow 32 ha), and Gordon Valley ( $>50 \%$ use, aspen stand $5 \mathrm{ha}$, meadow $50 \mathrm{ha}$ ).

\section{Data Collection}

Data collection was timed to capture early-, mid-, and lategrowing season grazing periods in both 2006 and 2007. Sample collection events were focused within 2-wk time frames representing each growing season period (Table 1). Growing season periods were based on phenological development of J. balticus and F. idahoensis: early-growing season-plants were in the active vegetative growth phase; mid-growing season-plants were in the seed set stage; and late-growing season-plants were senescing. The sampling periods were earlier in 2007 relating to advanced phenology due to early snowmelt and plant growth following a dry winter $(49 \%$ of normal annual precipitation), as compared to the high precipitation winter of 2006 (132\% of normal annual precipitation).

We measured biomass, utilization of biomass by cattle, nutritional quality attributes, and water content (succulence) of the herbaceous vegetation in each meadow and adjacent aspen stand. The same measurements were taken for aspen suckers $<1.5 \mathrm{~m}$ tall (cattle browse line) with the exception for biomass, and utilization was based on number of suckers browsed. These measurements were repeated early-, mid-, and late-growing season during 2006 and 2007 with the exception of vegetation water content, which was only measured in 2007. Five paired plots, each consisting of one subplot $\left(1 \mathrm{~m}^{2}\right)$ protected from cattle grazing using a wire cage and one subplot unprotected from cattle grazing $\left(1 \mathrm{~m}^{2}\right)$, were established in the meadow and adjacent aspen stand (10 paired plots per aspen-meadow complex). Paired plots were located to proportionately represent the extent of dominant herbaceous plant communities present within each meadow and aspen stand. To allow repeated sampling of each subplot through the year, we used the comparative yield method to estimate total biomass $\left(\mathrm{kg} \cdot \mathrm{ha}^{-1}\right)$ within each subplot (Interagency Technical Reference [ITR] 1996).

Percent utilization by cattle of meadow and aspen understory herbaceous vegetation was calculated from the difference between total standing biomass within the unprotected (grazed) plot and the total standing biomass within the protected (nongrazed) plot divided by the total standing biomass of the protected plot. Percent vegetation utilization for each meadow and aspen stand during early-, mid-, and late-growing/grazing season was the average of the five paired plots. Percent utilization of aspen suckers was measured along two $30 \times 2 \mathrm{~m}$ permanent belt transects randomly established in each aspen stand. Cattle utilization was determined by calculating the number of aspen suckers with browsed terminal leaders and/or lateral branches by the total number of aspen stems that were less than $1.5 \mathrm{~m}$ tall. Utilization measurement methods used in this study are standard methods used by public land resource managers in the region to assess cattle use of aspen and meadow vegetation, and make adaptive grazing management decisions.

Five vegetation samples were collected in both the meadow and aspen understory and one for the aspen suckers, for a total of 11 samples at each site for each sampling period. Composite herbaceous samples were collected around each paired plot, within the plant community represented by the plot. Vegetation was collected in proportion to species found in the paired plot. A composite sample of leaves was collected from aspen suckers near the two aspen utilization transects. A minimum of $30 \mathrm{~g}$ dry weight was collected for each sample. Samples were oven-dried at $50^{\circ} \mathrm{C}$ for $48 \mathrm{~h}$. Crude protein $(\mathrm{CP})$ was determined by nitrogen gas analyzer utilizing induction furnace and thermal conductivity. Acid detergent fiber (ADF) was determined using acid detergent, sulfuric acid, and heat. Calcium $(\mathrm{Ca})$ and phosphorous $(\mathrm{P})$ were determined by microwave acid digestion/ dissolution of sample and quantitative determination. Selenium (Se) was determined by nitric/perchloric acid digestion/dissolution and determination via vapor generation by inductively coupled plasma atomic emission spectroscopy. Nutritional quality analyses were conducted at the University of California Agriculture and Natural Resources Analytical Laboratory, University of California, Davis, California. For samples collected in 2007, percent water content by weight was determined as the difference between field weight at collection (wet) and the post oven (dry) sample weight.

\section{Data Analysis}

Linear mixed model regression analyses were used to test for differences in seasonal patterns of quantity, nutritional quality, and utilization by cattle between vegetation types. A backward stepping approach was used to determine the significance of associations between the independent fixed effects of year (2006, 2007), season (early, mid, late), vegetation type (meadow herbaceous, aspen understory herbaceous, aspen suckers), and the dependent variables of $\mathrm{CP}, \mathrm{ADF}, \mathrm{Ca}, \mathrm{P}, \mathrm{Ca}$ to $\mathrm{P}$ ratio $(\mathrm{Ca}: \mathrm{P})$, Se, water content, biomass, and percent utilization. Two-way interactions between year, season, and vegetation type were included in the initial saturated model. 
For all nutritional quality attributes, aspen-meadow complex identity was set as a random group effect to account for within site error and provide a nonsite specific result for extrapolation across the population of inference. Paired plot identity was set as a random intercept, nested within aspen-meadow complex identity, to account for repeated measures made on each paired plot (sample unit). Aspen-meadow complex identity was set as the random intercept for mixed effects analysis of biomass and utilization due to use of stand and meadow average measurements per visit in these analyses. Normality of residuals and homogeneity of variance was evaluated using standard diagnostic graphs (Pinheiro and Bates 2000). Ca:P ratio was $\log _{10}$ transformed, and percent utilization was $\left(\log _{10}+1\right)$ transformed. An exponential variance function was used in the analysis for protein to create homogeneity of variance. A $P$-value $<0.05$ was required for inclusion in each final linear mixed effects regression model.

\section{RESULTS}

\section{Growing Conditions}

Precipitation during 2006 and 2007 was $505 \mathrm{~mm}$ and $186 \mathrm{~mm}$, respectively, approximately $132 \%$ and $49 \%$ of normal. Mean annual temperatures for 2006 and 2007 were $4{ }^{\circ} \mathrm{C}$ and $4.5^{\circ} \mathrm{C}$. Mean growing season temperature was $14.1^{\circ} \mathrm{C}$ in 2006 , as compared to $13.4^{\circ} \mathrm{C}$ during 2007 .

\section{Vegetation Nutritional Quality}

Vegetation nutritional quality attributes measured generally declined with seasonal advance (i.e., declining $\mathrm{CP}$ and $\mathrm{P}$; increasing ADF; Fig. 1). Ca was the only nutrient with increasing values through the season in all vegetation types. Regardless of season, aspen suckers had significantly higher $(P<0.05)$ nutritional quality compared to meadow and aspen understory vegetation, which had similar quality $(P>0.05)$. Se values were below detection limit $(<0.05 \%)$ for all samples and Se was dropped from analysis.

Vegetation type, season, and year were significant main effects in final regression models for ADF, Ca, CP, P, and Ca:P (Table 2). ADF, Ca, and $\mathrm{P}$ each had a significant interaction of vegetation type by year and vegetation type by season. The $\mathrm{CP}$ model contained a vegetation type by year and season by year interaction. Vegetation type by season and season by year were significant for the Ca:P model.

The significant season by vegetation type interaction indicates that the seasonal change for nutritional quality attributes for aspen suckers was different compared to meadow and aspen understory vegetation. The total seasonal increase in $\mathrm{ADF}$ was lowest for aspen suckers at $3 \%$, compared to $13 \%$ and $14 \%$ increase for aspen understory and meadow, respectively. In contrast, the rates of change in $\mathrm{P}$ and $\mathrm{Ca}: \mathrm{P}$ were greater in aspen suckers compared to meadow and aspen herbaceous understory. Models for $\mathrm{CP}$ and $\mathrm{Ca}: \mathrm{P}$ contained a season by year interaction indicating seasonal change in these nutritional attributes varied by year. Compared to 2006, CP levels in 2007 decreased more quickly and Ca:P increased more quickly through the season (Fig 1). The vegetation type by year interaction was significant for $\mathrm{ADF}, \mathrm{Ca}$, and $\mathrm{P}$ and indicates these attributes varied by year.

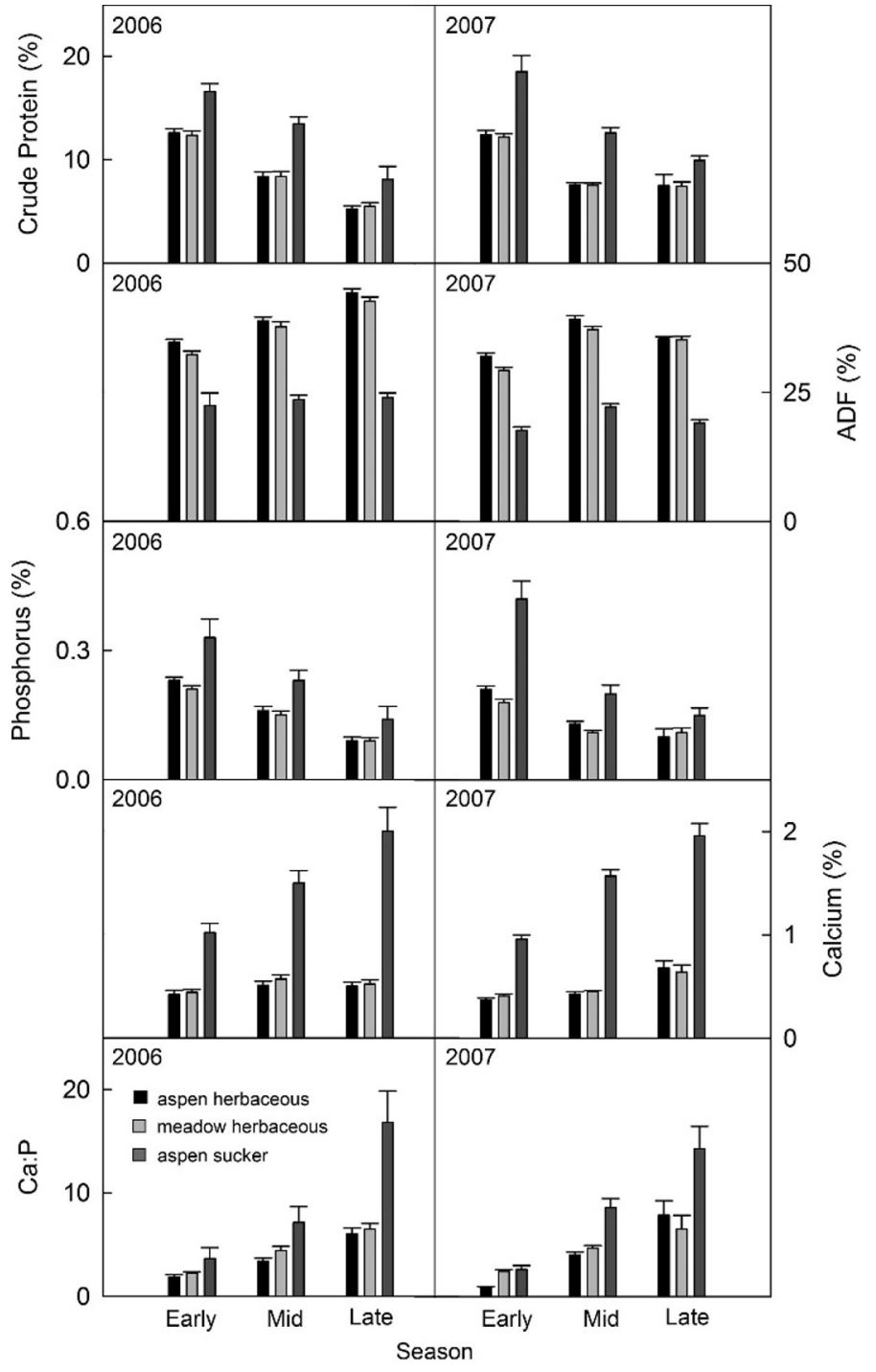

Figure 1. Mean values ( $\pm 1 \mathrm{SE}$ ) for nutritional quality attributes measured for aspen herbaceous vegetation, meadow herbaceous vegetation, and aspen suckers during early-, mid-, and late-growing grazing season for 2006 and 2007 across six aspen-meadow complexes on the Eagle Lake Ranger District, Lassen National Forest, California. ADF is acid detergent fiber and $\mathrm{Ca}: \mathrm{P}$ is calcium (Ca) to phosphorus (P) ratio.

\section{Biomass}

Year, season, vegetation type (meadow and aspen herbaceous understory only in this analysis), and the year by vegetation type interaction were significant predictors of herbaceous biomass (Table 2). There was an overall decrease in biomass through the season for both vegetation types in 2007 (Fig. 2), and biomass was lower in 2007 compared to 2006. Biomass was higher in meadows, but the difference in biomass between meadow and aspen understory vegetation depended on year. In 2006, there was significantly more biomass in meadows compared to aspen understory.

\section{Water Content}

Water content was only measured during 2007 (Fig. 3). Water content of aspen suckers was significantly greater than 
Table 2. Results of linear mixed model analysis to determine differences in seasonal nutritional quality attributes, biomass, and utilization by cattle among three vegetation types: meadow, aspen understory, and aspen suckers. Data analyzed were from six aspenmeadow complexes on the Eagle Lake Ranger District, Lassen National Forest, California, from the 2006 and 2007 summer growing season. Mixed model results are displayed for acid detergent fiber (ADF), crude protein $(\mathrm{CP})$, calcium $(\mathrm{Ca})$, phosphorus $(\mathrm{P})$, Ca to $\mathrm{P}$ ratio $(\mathrm{Ca}: \mathrm{P})$, standing biomass, and percent utilization by weight by cattle.

\begin{tabular}{lccccccc}
\hline \multicolumn{1}{c}{ Model term } & ADF & CP & Ca & P & Ca:P & Biomass & Utilization \\
\hline Year (Y) & $\mathrm{ns}^{1}$ & $\mathrm{~ns}$ & $\mathrm{~ns}$ & $* * *$ & $\mathrm{~ns}$ & $* * *$ & $\mathrm{nS}$ \\
Season (S) & $* * *$ & $* * *$ & $* * *$ & $* * *$ & $* * *$ & $* * *$ & $* * *$ \\
Vegetation type (V) & $\mathrm{ns}$ & $* * *$ & $* * *$ & $* * *$ & $* *$ & $* * *$ & $* * *$ \\
$\mathrm{~V} \times \mathrm{Y}$ & $* * *$ & $* * *$ & $* * *$ & $*$ & $\mathrm{nS}$ & $* * *$ & $\mathrm{nS}$ \\
$\mathrm{V} \times \mathrm{S}$ & $* * *$ & $\mathrm{~ns}$ & $* * *$ & $* *$ & $* *$ & $\mathrm{nS}$ & $* * *$ \\
$\mathrm{~S} \times \mathrm{Y}$ & $\mathrm{ns}$ & $* * *$ & $\mathrm{~ns}$ & $\mathrm{~ns}$ & $* * *$ & $\mathrm{~ns}$ & $\mathrm{~ns}$ \\
\hline
\end{tabular}

${ }^{1}$ ns indicates $P>0.05 ;{ }^{*}, P \leq 0.05 ;{ }^{* *}, P<0.01 ;{ }^{* * *}, P<0.005$.

aspen and meadow herbaceous vegetation regardless of season $(P<0.05)$. Water content in aspen understory and meadow vegetation decreased significantly with each successive season $(P<0.05)$, while water content of aspen suckers maintained relatively high levels throughout the grazing season.

\section{Cattle Utilization}

Vegetation type, season, and the season by vegetation type interaction were significant predictors of cattle utilization (Table 2). Utilization increased for all vegetation types through the grazing season with differential utilization among the vegetation types (Fig. 4). As the season progressed, cattle use on aspen suckers increased exponentially and in some stands reached $100 \%$. Meadow and aspen understory vegetation had statistically similar utilization regardless of season $(P>0.05)$. Meadow and aspen understory vegetation use was greater than aspen suckers in the early-growing season and less than aspen suckers by late-growing season $(P<0.05)$. Use of meadow and aspen understory vegetation increased more uniformly across the grazing season compared to aspen sucker use.

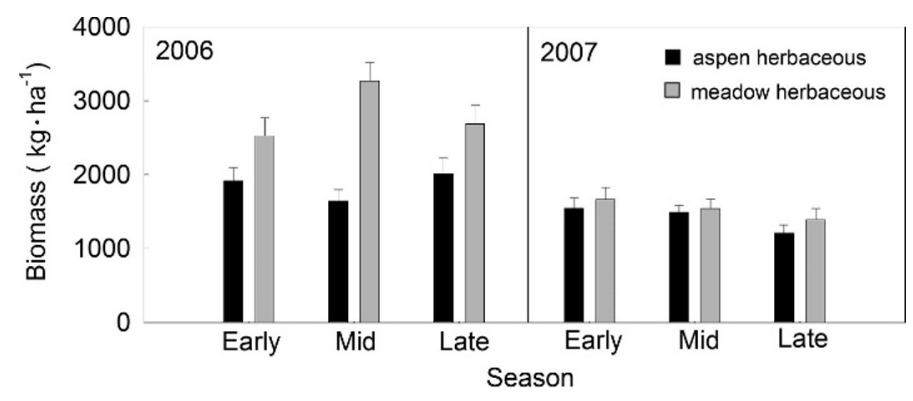

Figure 2. Mean biomass ( $\pm 1 \mathrm{SE}$ ) measured for aspen and meadow herbaceous vegetation during early-, mid-, and late-growing grazing season for 2006 and 2007 at six aspen-meadow complexes on the Eagle Lake Ranger District, Lassen National Forest, California.

\section{DISCUSSION}

Cattle use varied among vegetation types by season. Aspen suckers received no early-growing season use by cattle but received the heaviest late-growing season use of all three vegetation types (Fig. 4). Utilization was the same for all vegetation types at mid-growing season. Mean late-growing season use of aspen suckers was greater than $60 \%$, and some stands received $100 \%$ use. Utilization was statistically the same between meadow and aspen understory herbaceous vegetation. Late-growing season utilization of aspen herbaceous and meadow herbaceous vegetation ranged from $10 \%$ to $75 \%$ with an average of $41 \%$.

Regardless of season or year, aspen suckers had higher nutritional quality than aspen understory or meadow herbaceous vegetation (Fig. 1). However, despite the higher quality of aspen suckers during early-growing season, cattle predominately consumed meadow and aspen understory vegetation during this season. During early-growing season, meadow and aspen understory vegetation were available in relatively large quantities with meadows producing the most biomass of all types (Fig. 2). During early-growing season both meadow and aspen understory vegetation fully met the general nutrient requirements of $\mathrm{CP}, \mathrm{P}$, and $\mathrm{Ca}(9.9 \%, 0.2 \%$, and $0.3 \%$, respectively) for lactating beef cows (National Research Council [NRC] 1996). The combination of adequate quantity and quality may explain the principal utilization of these two vegetation types by cattle in early-growing season. We did not measure chemical constituents that deter herbivores, which may also influence cattle diet selection in the early-growing season. There is limited information about aspen tannins and phenolic glycosides deterring mammalian browsing, although Erwin et al. (2001) suggest that phenolic glycosides are more effective than tannins. Both compounds vary with respect to aspen genotype. Concentrations of tannins increase with season while phenolic glycosides trends over season vary among aspen clones (Lindroth et al. 1987; Osier et al. 2000). Ginane et al. (2003) also observed that cattle select for relatively lower quality vegetation in high quantity over higher quality and lower availability. Willms and Rode (1998) observed that cattle

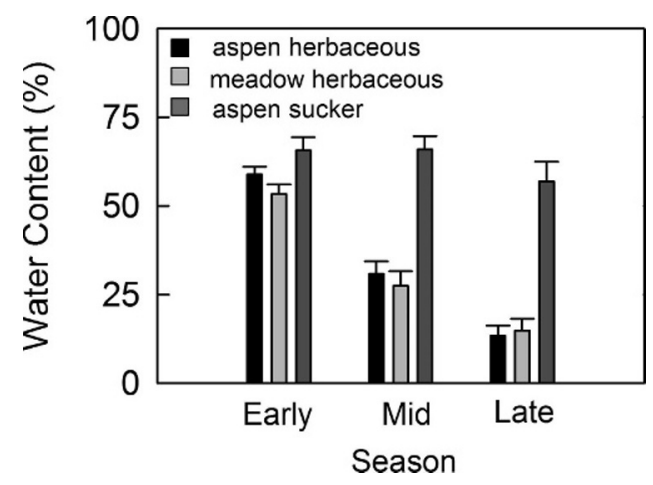

Figure 3. Mean water content ( \pm 1 SE) measured for aspen herbaceous vegetation, meadow herbaceous vegetation, and aspen suckers during early-, mid-, and late-growing grazing season during 2007 at six aspen-meadow complexes on the Eagle Lake Ranger District, Lassen National Forest, California. 


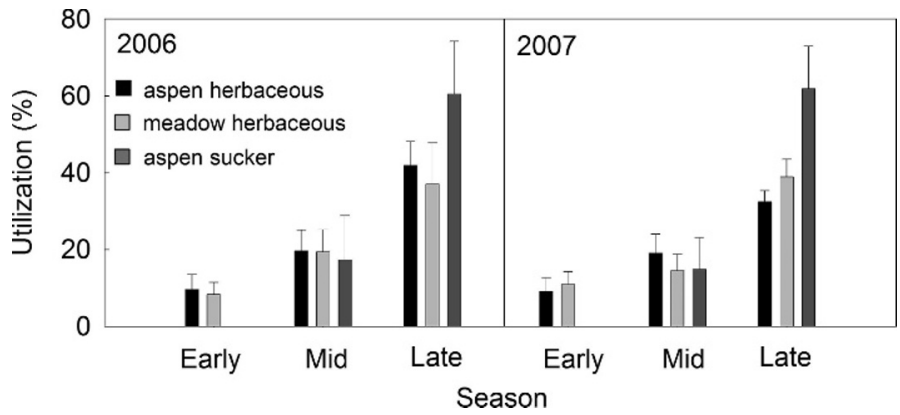

Figure 4. Mean utilization ( $\pm 1 \mathrm{SE}$ ) by cattle measured for aspen herbaceous vegetation, meadow herbaceous vegetation, and aspen suckers during early-, mid-, and late-growing grazing season for 2006 and 2007 at six aspen-meadow complexes on the Eagle Lake Ranger District, Lassen National Forest, California. There was no utilization of aspen during the early season of 2006 and 2007.

select plant species with the greatest biomass regardless of supplementation.

Herbaceous plant species in meadow and aspen understory began to senesce by mid-growing season, as illustrated by significantly reduced water content (Fig. 3). Aspen sucker water content remained high throughout the grazing season, reflecting relatively greater nutritional quality and thus driving utilization of aspen suckers by cattle in the mid-growing season and late-growing season. By mid-growing season, the quality of meadow and aspen understory vegetation approached minimum nutritional levels required for cattle. Available biomass decreased in herbaceous vegetation types due to utilization and palatability, as defined by water content and ADF. Biomass availability, CP, and water content are positively associated with vegetation selection by cattle (Roath and Krueger 1982; Senft et al. 1985; Pinchak et al. 1991). Mid-growing season decreases in meadow and aspen understory vegetation quantity and quality coincided with a marked increase in aspen utilization during both study years. At mid-growing-season, mean $\mathrm{CP}, \mathrm{P}$, and $\mathrm{Ca}$ levels in aspen suckers exceeded lactating beef cattle minimum nutrient requirements $(9.3 \%, 0.2 \%$, and $0.3 \%$ respectively). Although $\mathrm{P}$ and Ca levels were highest in aspen suckers, mean Ca:P ratio was 7 (Fig. 1) and the ideal Ca:P for cattle is 2:1. Ratios of 7:1 are acceptable, but $\mathrm{P}$ becomes unavailable when the ratio exceeds 7 (NRC 1984). The differential in digestibility (ADF) between aspen suckers and meadow and aspen understory vegetation was greater in mid-growing-season compared to early-growing season (Fig. 1). As plants grow, structural carbohydrates, including cellulose, hemicelluloses, and lignin, all increase. Cattle can digest cellulose and hemicelluloses through rumen microbial action, but they cannot digest lignin (Crampton and Maynard 1938; Gray 1947). The major increase in lignin content occurs when plants change from the elongation stage to the reproductive stage (Chen et al. 2002). Vegetation containing high ADF values have lower digestible energy concentration and can restrict dry matter intake, ultimately decreasing the amount of energy cattle receive (Arnold et al. 1966; Moore and Jung 2001). Therefore, aspen suckers, with ADF levels never exceeding $28 \%$ provided a higher quality diet that meets energy demands of cattle. Moreover, the demand for metabolizable energy is highest when cow-calf pairs are present and cows are lactating. Cow calf pairs were present on our study sites contributing to the higher utilization of aspen suckers starting mid-growing-season.

In all three vegetation types, nutritional quality and available biomass for meadow and aspen understory were at the lowest levels by late-growing season. Decreases in biomass, nutritional quality, and water content were less from mid- to late-growing season compared to early- to mid-growing season. Lategrowing season $\mathrm{CP}$ in aspen suckers achieved lactating beef cow nutrient requirements $(7.9 \%)$, whereas meadow and aspen understory vegetation fell below this requirement (Fig. 1). The differential might have resulted in the higher utilization of aspen suckers by late-growing season. It was likely that the combination of decreased meadow and aspen understory vegetation quantity and nutritional quality lead to increased utilization on aspen suckers, particularly mid- to late-growing season. Similar temporal patterns of utilization on woody vegetation such as willow and cottonwood has been observed and was associated with reduced herbaceous abundance or palatability (Roath and Krueger 1982; Kauffman et al. 1983; Matney et al. 2005).

Our results illustrate seasonal trends and differences in the quality, quantity, and utilization of meadow, aspen understory, and aspen suckers. Cattle utilization patterns observed in this study were consistent with optimal foraging theory and hierarchical foraging models (MacArthur and Pianka 1966; O’Reagain and Grau 1995). As preferred vegetation becomes scarce, cattle widen their choice of diet by adding different vegetation types to meet their nutritional needs (Emlen 1966; Pyke et al. 1977). Cattle utilization of aspen appears to be driven by seasonal differences in the nutritional quality of aspen suckers and quantity of other available vegetation types in the system. Grazing management strategies that balance seasonally dynamic vegetation availability, quality, livestock nutritional needs, and season of use can benefit both livestock production and aspen restoration goals.

\section{MANAGEMENT IMPLICATIONS}

Seasonal utilization of different vegetation types by cattle is a function of relative vegetation quantity, nutritional quality, and cow nutrient demand. Managers must consider all three aspects when developing seasonal grazing strategies for meadows and adjacent aspen communities. A clear grazing management goal for the restoration of aspen must be to limit defoliation intensity on aspen suckers during mid- and late-growing season (Jones et al. 2009). In this paper, we illustrate the challenge presented to the manager by the increasing nutritional quality differential between aspen suckers and herbaceous vegetation as the annual growing season progresses. Our results indicate increased cattle preference for aspen as the season progresses. Season of grazing should be managed annually to insure that mid- and late-growing season use does not occur in consecutive years. Early-growing season only grazing in management units with aspen essentially creates rest from grazing for aspen stands, due to low cow preference for aspen during this period. Season of use and rest from grazing can be managed via rotational grazing strategies such as rest rotation. It is also important to set stocking rates such that herbaceous vegetation 
quantity is not limiting, which potentially increases utilization of aspen. Annual variation in precipitation and biomass production must be accounted for in grazing strategies, with attention paid to low herbaceous vegetation production years when use of aspen could occur earlier in the growing season, compared to wetter years. Finally, it is important that managers provide nutritional supplements to insure that a source of protein and other essential nutrients is available to cattle, as opposed to aspen serving as a supplement source.

\section{LITERATURE CITED}

Arnold, G. W., J. Ball, W. R. McManus, and I. G. Bush. 1966. Studies on the diet of the grazing animal I. Seasonal changes in the diet of sheep grazing on pastures of different availability and composition. Australian Journal of Agricultural Resources 17:543-556.

Arnold, G. W., AND M. L. Dudzinski. 1978. Ethology of free-ranging domestic animals. Amsterdam: Elsevier. 198 p.

Baker, W. L., J. A. Munroe, and A. E. Hessl. 1997. The effects of elk on aspen in the winter range in Rocky Mountain National Park. Ecography 20:155-165.

BarToS, D. L. 2001. Landscape dynamics of aspen and conifer forest. In: W. D. Shepperd, D. Binkley, D. L. Bartos, T. J. Thomas, and L. G. Eskew [EDS.]. Symposium Proceedings: Sustaining Aspen in Western Landscapes. Grand Junction, CO, USA: US Department of Agriculture Forest Service Rocky Mountain Research Station. RMRS-P-18. p. 5-14.

Bartos, D. L. 2007. Aspen. In: S. M. Hood and M. Miller [eds.]. Fire ecology and management of the major ecosystems of southern Utah. Fort Collins, CO, USA: US Department of Agriculture, Forest Service Rocky Mountain Research Station. RMRS-GTR-202. p. 39-55.

Bartos, D. L., J. K. Brown, AND G. D. Booth. 1994. Twelve years biomass response in aspen communities following fire. Journal of Range Management 47:79-83.

Bartos, D. L., and R. B. CampbelL, Jr. 1998. Decline of quaking aspen in the interior West-examples from Utah. Rangelands 20:17-24.

Belovsky, G. E. 1984. Herbivore optimal foraging: a comparative test of three models. American Naturalist 124:97-115.

BINKLEY, D. 2008. Age distribution of aspen in Rocky Mountain National Park, USA. Forest Ecology and Management 255:797-802.

Chen, L., G. Auh, F. Chen, X. Cheng, H. Aluoe, R. A. Dixon, and Z. Wang. 2002. Lignin deposition and associated changes in anatomy, enzyme activity, gene expression, and rumial degradability in stems of tall fescue at different developmental stages. Journal of Agriculture and Food Chemistry 50: $5558-5565$.

Chong, G. W., S. E. Simonson, T. J. Stohlgren, and M. A. Kalkahan. 2001. Biodiversity: aspen stands have the lead, but will nonnative species take over? In: W. D. Shepperd, D. Binkley, D. L. Bartos, T. J. Stohlgren, and L. G. Eskew [EDS.]. Symposium Proceedings: Sustaining Aspen in Western Landscapes. Grand Junction, CO, USA: US Department of Agriculture, Forest Service Rocky Mountain Research Station. RMRS-P-18. p. 261-271.

Crampton, E. W., and L. A. Maynard. 1938. The relation of cellulose and lignin content to the nutritive value of animal feeds. Journal of Nutrition 15:383.

DeByLE, N. V. 1985. Management for esthetics and recreation, forage, water, and wildlife. In: N. V. DeByle and R. P. Winokur [EDs.]. Aspen: ecology and management in the western United States. Fort Collins, CO, USA: US Department of Agriculture Forest Service, Rocky Mountain Forest and Range Experiment Station. General Technical Report RM-119. p. 223-232.

Di'Orio, A. P., R. Callas, and R. J. Schaefer. 2005. Forty-eight year decline and fragmentation of aspen (Populus tremuloides) in the South Warner Mountains of California. Forest Ecology and Management 206:307-313.

Dockrill, C. W. M., P. I. V. Blenis, A. W. Bailey, and J. R. King. 2004. Effect of summer cattle grazing on aspen stem injury, mortality and growth. Forestry Chronicle 80:257-261.

Emlen, J. M. 1966. The role of time and energy in food preference. The American Naturalist 100:611-617.
ERIKSson, 0. 1993. Dynamics of genets in clonal plants. Trends in Ecology and Evolution 8:313-316.

Erwin, E. A., M. G. Turner, R. L. Lindeoth, And W. H. Romme. 2001. Secondary plant compounds in seedling and mature aspen (Populus tremuloides) in Yellowstone National Park, Wyoming. American Midland Naturalist 145:299-308.

Frey, B. R., V. J. Lieffers, E. H. Hogg, and S. M. Landhausser. 2004. Predicting landscape patterns of aspen dieback: mechanisms and knowledge gaps. Canadian Journal of Forest Research 34:1379-1390.

Ginane, C., M. Petit, and P. D'Hour. 2003. How do grazing heifers choose between maturing reproductive and tall or short vegetative swards? Applied Animal Behavior Science 83:15-27.

GraY, F. V. 1947. The digestion of cellulose by sheep: the extent of cellulose digestion at successive levels of the alimentary tract. Journal of Experimental Biology 24:15.

Green, D. M., And J. B. Kauffman. 1995. Succession and livestock grazing in a northeastern Oregon riparian ecosystem. Journal of Range Management 48: 307-313.

[ITR] Interagency Technical Reference. 1996. Utilization studies and residual measurements. BLM/RS/ST-96/004+1730. Interagency Technical Reference. Denver, CO, USA: U.S. Bureau of Land Management. 165 p.

Jones, B. E., D. F. Lile, And K. W. Tate. 2009. Effect of simulated browsing on growth of aspen regeneration: implications for restoration. Rangeland Ecology \& Management 62:557-563.

Jones, B. E., T. H. Rickman, A. Vazquez, Y. Sado, and K. W. Tate. 2005. Removal of encroaching conifers to regenerate degraded aspen stands in the Sierra Nevada. Restoration Ecology 13:373-379.

Kashian, D. M., W. H. Romme, and C. M. Regan. 2007. Reconciling divergent interpretations of quaking aspen decline on the northern Colorado front range. Ecological Applications 17:1296-1311.

Kauffman, J. B., W. C. Krueger, and M. Vavra. 1983. Effects of late-growing season cattle grazing on riparian plant-communities. Journal of Range Management 36:685-691.

KAY, C. E. 1993. Aspen seedlings in recently burned areas of Grand Teton and Yellowstone National Park. Northwest Science 67:94-104.

KaY, C. E. 2001. Long-term aspen exclosures in the Yellowstone ecosystem. In: W. D. Shepperd, D. Binkley, D. L. Bartos, T. J. Stohlgren, and L. G. Eskew [EDS.]. Symposium Proceedings: Sustaining Aspen in Western Landscapes. Grand Junction, CO, USA: US Department of Agriculture, Forest Service Rocky Mountain Research Station. RMRS-P-18. p. 225-240.

KAY, C. E., AND D. L. BARTOS. 2000. Ungulate herbivory on Utah aspen: assessment of long-term exclosures. Journal of Range Management 52:145-154.

Kaye, M. W., D. Binkley, and T. J. Stohlgren. 2005. Effects of conifers and elk browsing on quaking aspen forest in the central Rocky Mountains, USA. Ecological Applications 15:1284-1295.

KoukI, J., K. Arnold, and P. Martikainen. 2004. Long-term persistence of aspena key host for many threatened species-is endangered in old-growth conservation areas in Finland. Journal for Nature Conservation 12:41-52.

Kulakowski, D., T. T. Veblen, and S. Drinkwater. 2004. The persistence of quaking aspen (Populus tremuloides) in the Grand Mesa area, Colorado. Ecological Applications 14:1603-1614.

Kulakowski, D., T. T. Veblen, and B. P. Kunzel. 2006. Influence of infrequent fire, elevation, and pre-fire vegetation on the persistence of quaking aspen (Populus tremuloides Michx.) in the Flat Tops area, Colorado, USA. Journal of Biogeography 33:1397-1413.

Lindroth, R. L., M. T. Stephen Hsia, and J. Mark Scriber. 1987. Seasonal patterns in phytochemistry of three Poulus species. Biochemical Systematics and Ecology 16:681-686.

MacArthur, R. H., and E. R. Pianka. 1966. On optimal use of a patchy environment. American Naturalist 100:603-609.

Matney, C. A., C. S. Boyd, and T. K. Stringham. 2005. Use of felled junipers to protect streamside willows from browsing. Rangeland Ecology \& Management 58:652-655.

McWilliam, E. L., T. N. Barry, and N. Lopez-Villalobos. 2005. Organic matter digestibility of poplar (Populus) and willow (Salix) forage trees and its in vitro prediction. Journal of Science of Food and Agriculture 85:1098-1104. 
Miller, G. R., and R. P. Cummins. 1982. Regeneration of Scots pine Pinus sylvestris at a natural tree-line in Cairngorm Mountains, Scotland. Holarctic Ecology 5:27-34.

MooRe, K. J., AND J. G. Jung. 2001. Lignin and fiber digestion. Journal of Range Management 54:420-430.

Mueggles, W. F. 1985. Forage. In: N. V. Debyle and R. P. Winokur [eds.]. Aspen: ecology and management in the western United States. Fort Collins, CO, USA: US Forest Service Rocky Mountain Research Station. US Department of Agriculture Forest Service General Technical Report RM-119. p. 129-134.

[NRC] National Research Councli. 1984. Nutrition requirements of beef cattle (6th ed.). Washington, DC, USA: National Academy Press. $90 \mathrm{p}$.

NRC. 1996. Nutrition requirements of beef cattle (7th revised ed.). Washington, DC, USA: National Academy Press. 234 p.

O'Reagain, P. J., and E. A. Grau. 1995. Sequence of species selection by cattle and sheep on South African sourveld. Journal of Range Management 48(4):314-321.

Osier, T. L., S. Y. Hwang, and R. L. Lindroth. 2000. Within- and between-year variation in early season phytochemistry of quaking aspen (Populus tremuloides Michx.) clones. Biochemical Systematics and Ecology 28:197-208

Peterken, G. F., and C. R. Tubbs. 1965. Woodland regeneration in the new forest, Hampshire, since 1650. Journal of Applied Ecology 2:159-170.

Pinchak, W. E., M. A. Smith, R. H. Hart, and J. W. Waggoner, Jr. 1991. Beef cattle grazing distribution patterns on foothill range. Journal of Range Management 44:267-275

PinheiRo, J. C., and D. M. Bates. 2000. Mixed effects models in S and S-Plus. New York, NY, USA: Springer. 528 p.

Pyke, G. H., H. R. Pulliam, and E. L. Charnov. 1977. Optimal foraging: a selective review of theory and tests. Quarterly Review of Biology 52:137-154.

Roath, L. R., and W. C. Krueger. 1982. Cattle grazing influence in a mountain riparian zone. Journal of Range Management 35:100-104.

Rogers, P. 2002. Using forest health monitoring to assess aspen forest cover change in the southern Rockies ecoregion. Forest Ecology and Management 155:223-236.

RoLF, J. M. 2001. Aspen fencing in northern Arizona: a 15-year perspective. In: W. D. Shepperd, D. Binkley, D. L. Bartos, T. J. Stohlgren, and L. G. Eskew [EDS.]. Symposium Proceedings: Sustaining Aspen in Western Landscapes. Grand Junction, CO, USA: US Department of Agriculture, Forest Service Rocky Mountain Research Station. RMRS-P-18. p. 193-196.

Romme, W. H., M. G. Turner, R. H. Gardner, W. W. Hargrove, G. A. Tuskan, D. G. Despain, and R. A. Renkin. 1997. A rare episode of sexual reproduction in aspen (Populus tremuloides Michx.) following the 1988 Yellowstone fires. Natural Areas Journal 17:17-25.

SANKEY, T. T. 2008. Learning from spatial variability: aspen persistence in the Centennial Valley, Montana. Forest Ecology and Management 255:1219-1225.

SCHIER, G. A. 1976. Physiological and environmental factors controlling vegetative regeneration of aspen. In: D. L. Hessel, D. R. Betters, T. J. Loring, L. D. Porter, and J. E. Bennett [EDS.]. Symposium Proceedings: Utilization and Marketing as Tools for Aspen Management in the Rocky Mountains. Fort Collins, CO, USA: US Department of Agriculture, Forest Service Rocky Mountain Research Station. RM-GTR-29. p. 20-23.

Semiadi, G., T. N. Barry, P. D. Muir, and J. Hodgson. 1995. Dietrary preferences of sambar (Cervus unicolor) and red deer (Cervus elphus) offered browse, forage legume and grass species. Journal of Agricultural Science 125:99-107.

Senft, R. L., M. B. Coughenour, D. W. Balley, R. L. Rittenhouse, O. E. Sala, and D. M. SwiFt. 1987. Large herbivore foraging and ecological hierarchies. Bioscience 37:789-799.

Senft, R. L., R. L. Rittenhouse, and R. G. Woodmansee. 1985. Factors influencing patterns of cattle grazing behavior on shortgrass steppe. Journal of Range Management 38:82-87.

Shepperd, W. D., P. C. Rogers, D. Burton, and D. L. Bartos. 2006. Ecology, biodiversity, management, and restoration of aspen in the Sierra Nevada. Fort Collins, CO, USA: US Department of Agriculture, Forest Service Rocky Mountain Research Station. RMRS-GTR-178. 122 p.

TILGhman, N. G. 1989. Impacts of white-tailed deer on forest regeneration in northwestern Pennsylvania. Journal of Wildlife Management 53:524-532.

Turner, M. G., W. H. Romme, and D. B. Tinker. 2003. Surprises and lessons from the 1988 Yellowstone fires. Frontiers in Ecology and the Environment 1:351-358.

White, C. A., C. E. Olmsted, and C. E. Kay. 1998. Aspen, elk, and fire in Rocky Mountain national parks of North America. Wildlife Society Bulletin 26:449-462.

Willms, W. D., AND L. M. Rode. 1998. Forage selection by cattle on fescue prairie in summer or winter. Journal of Range Management 51:496-500.

Worrall, J. J., L. E. Egeland, T. Eager, R. A. Mask, E. W. Johnson, P. A. Kemp, and W. D. ShepPERD. 2008. Rapid mortality of Populus tremuloides in southwestern Colorado, USA. Forest Ecology and Management 255:686-696.

ZakRISSON, C., G. ERICSSON, And L. Edenius. 2007. Effects of browsing on recruitment and mortality of European aspen (Populus tremula L.). Scandinavian Journal of Forest Research 22:324-332. 